\title{
Acquired von Willebrand disease: from theory to practice. A single center experience - three case reports
}

\author{
Boala von Willebrand dobândită: de la teorie la practică. Experiența \\ unicentrică - trei prezentări de cazuri
}

\author{
Andrei Colită ${ }^{1,2^{*}}$, Carmen Saguna ${ }^{1,2}$, Andra Costache ${ }^{1}$, Gabriela Borsaru ${ }^{2}$, Raluca \\ Manolache $^{2}$, Ana Maria Ivănescu ${ }^{2}$, Anca Roxana Lupu ${ }^{1,2}$ \\ 1. University of Medicine and Pharmacy "Carol Davila", 2. Coltea Hospital Bucharest, Romania
}

\begin{abstract}
Acquired von Willebrand disease (AvWD) represents a rare, potentially severe and most likely underdiagnosed category of hemorrhagic syndromes determined by quantitative, qualitative or functional, nonhereditary, alterations of von Willebrand factor ( $(\mathrm{WF})$ that occur in the context of various underlying diseases. It is diagnosed mainly in adults, without any personal or familial history of bleeding. The etiopathogeny of AvWD is complex, marked by the intervention of multiple mechanisms, occuring in the evolution of neoplasia, autoimmune disorders, cardiovascular diseases and other conditions. The clinical and laboratory manifestations are similar to the congenital form with mucocutaneous hemorrhage in patients without bleeding history and demonstration of quantitative and/or functional anomalies of $v W F$. Treatment has two major objectives: control of bleeding and therapy of the underlying condition. As a practical illustration of the theoretical aspects we present 3 clinical cases of AvWD diagnosed in the Colţea Hospital Department of Hematology during the last 10 years.
\end{abstract}

Keywords: von Willebrand disease acquired

\section{Rezumat}

Boala von Willebrand dobândită (BvWD) reprezintă o categorie rară, potențial severă de sindroame hemoragice determinate de anomalii cantitative, calitative sau funcționale ale factorului von Willebrand $(F v W)$ ce pot apărea în evoluția unei varietăți de boli asociate. Boala este diagnosticată mai ales la adulți în lipsa unor antecedente hemoragice. Etiopatogenia este complexă, caracterizată prin acțiunea a diferite mecanisme care apar în neoplazii, boli autoimune, cardiovasculare sau alte afecțiuni. Manifestările clinice și de laborator sunt similare cu cele din forma ereditară, reprezentate de apariția de sângerări cutaneo-mucoase și a unor anomalii cantitative sau funcționale ale $F v W$. Tratamentul are drept obiective stăpânirea hemoragiilor și terapia bolilor asociate. Pentru a ilustra din punct de vedere practic aspectele teoretice discutate, vom prezenta 3 cazuri de BvWD diagnosticate in ultimii 10 ani în Clinica de Hematologie a Spitalului Colțea.

Cuvinte cheie: boala von Willebrand dobândită

Received: $20^{\text {th }}$ November 2015; Accepted: $9^{\text {th }}$ January 2016; Published: $29^{\text {th }}$ February 2016

*Corresponding author: Andrei Colită, University of Medicine and Pharmacy "Carol Davila”, Colțea Hospital Bucharest, Romania, e-mail: andreicolita@yahoo.com 
Von Willebrand factor (vWF) is a glycoprotein that plays a major role in normal hemostasis, by functioning as carrier protein for coagulation factor VIII and by mediating platelet adhesion to endothelial lesions. Mutations in the vWF gene result in quantitative and qualitative defects, characteristic for hereditary von Willebrand disease (vWD), the most common inherited coagulation disorder. Quantitative, qualitative or functional, nonhereditary alterations of vWF can also occur later in life, as acquired vWD [1-8].

Acquired von Willebrand disease (AvWD) represents a rare and most likely underdiagnosed (or misdiagnosed) category of hemorrhagic syndromes associated to a variety of underlying diseases. It is diagnosed mainly in adults, without any personal or familial history of bleeding. Clinical and laboratory manifestations are similar to those found in the congenital form [1-4]. Based on the several hundreds of cases reported in literature, the prevalence is evaluated at $0.04 \%$, probably highly underestimated [6-11].

The etiology of AvWD is heterogeneous including neoplasia, autoimmune disorders, cardiovascular diseases, therapeutic agents as well as a multitude of other conditions $[1,2,4,5$, 7,8,12-16].

Table 1 resumes the causes of AvWD.

The pathophysiology of AvWD is complex and not yet entirely understood. There are various proposed mechanisms for AvWD in different underlying diseases. Also for one given etiology more than one mechanism could lead to the bleeding condition. The vWF synthesis is decreased only in a minority of AvWD cases mainly those associated with hypothyroidism. In the majority of cases vWD synthesis in megakaryocytes and endothelial cells is normal or even increased, but there is an accelerated vWF clearance from patients' plasma $[1,2,4,5,7,8,17]$. The increased vWD clearance is mediated by a variety of mechanisms:
1. Presence of autoantibodies against vWF leading to the formation of immune complexes that are removed by macrophages of the reticuloendothelial system $[1,2,4,7,8,17]$

a. Specific anti-vWF autoantibodies with inhibitor function that are directed against GPIb binding sites in the presence of ristocetin, collagen, $\alpha \mathrm{IIb} \beta 3$; autoantibodies may also interfere with the assembling of multimers in the vWF molecule;

b. Nonspecific antibodies.

2. Adsorbtion of vWF onto cell's surface (malignant cells, activated platelets) or large molecules (drugs) [1,2,4,7,8,12,13,18-21]

a. Demonstrated in lymphoproliferative diseases or adrenal cell carcinoma by ectopic expression of GPIb or vWF on malignant cells;

b. In essential thrombocythemia large multimers of $\mathrm{vWF}$ are adsorbed on platelets;

c. In aortic valve stenosis, the high sheer stress induces platelet activation followed by large multimers adsorbtion;

d. Administration of hydroxyethyl starch (HES), a plasma expander, may lead to the adsorbtion of large multimers onto macromolecules of the drug.

3. Increased $v W F$ proteolysis was demonstrated in myeloproliferative diseases, cardiac valve diseases, uremia, and following ciprofloxacin treatment $[1,2,4,7,8$ 12,13,20];

4. Mechanical breakage of multimers secondary to high shear stress in severe aortic stenosis $[1,2,4,20,21]$.

Table 2 summarizes the mechanisms involved in AvWD.

The most important clinical sign is cutaneous and/or mucosal hemorrhage, same as for constitutional vWD: spontaneous ecchymosis, epistaxis, gum bleeding, gastrointestinal bleeding, hematuria, etc. Nonetheless, the AvWD diagnosis needs high clinical awareness when consulting 
Table 1. Causes of acquired von Willebrand disease $[1-5,7,8,12-16]$

\begin{tabular}{|c|c|}
\hline Lymphoproliferative disorders & $\begin{array}{l}\text { - Monoclonal gammopathy of undetermined significance, Multiple my- } \\
\text { eloma, Waldenstrom's macroglobulinemia } \\
\text { - Non-Hodgkin's lymphoma, chronic lymphocytic leukemia, hairy cell } \\
\text { leukemia }\end{array}$ \\
\hline Myeloproliferative disorders & $\begin{array}{l}\text { Essential thrombocythemia, polycytemia vera, chronic myeloid leuke- } \\
\text { mia }\end{array}$ \\
\hline Tumors & $\begin{array}{l}\text { Wilm's tumor, Ewing's sarcoma, adrenal cell carcinoma, } \\
\text { adenocarcinomas, other }\end{array}$ \\
\hline Autoimmune disorders & $\begin{array}{l}\text { Systemic lupus erythematosus, connective tissue disease, graft versus } \\
\text { host disease }\end{array}$ \\
\hline Endocrine disorders & Hypothyroidism \\
\hline Cardiovascular disorders /procedures & $\begin{array}{l}\text { Congenital cardiac anomalies, mitral valve prolaps, aortic stenosis, } \\
\text { ventricular assist devices, heart transplantation, coronary artery bypass } \\
\text { surgery, extracorporeal membrane oxygenation }\end{array}$ \\
\hline Drugs/therapeutic agents & $\begin{array}{l}\text { Antibiotics (ciprofloxacin, levofloxacin, cefotaxim, griseofulvin) } \\
\text { Anticonvulsivants (valproic acid) } \\
\text { Recombinant factor VII } \\
\text { Hidroxyethyl starch (HES) }\end{array}$ \\
\hline Other causes & $\begin{array}{l}\text { Uremia } \\
\text { Gastrointestinal angiodysplasia } \\
\text { Infections (viral, parasitic) } \\
\text { Ehlers Danlos syndrome } \\
\text { Gaucher's disease } \\
\text { Renal transplantation } \\
\text { Autologous stem cell transplantation } \\
\text { Lactoferrin deficiency } \\
\text { Hemoglobin E- } \beta \text { thalassemia } \\
\text { Turner syndrome } \\
\text { Diabetus mellitus }\end{array}$ \\
\hline
\end{tabular}

adult patients with such hemorrhagic manifestations appearing late in life, in the absence of personal or familial antecedents for coagulation disorders. The role of a careful discussion with patients in order to evaluate bleeding history has to be underlined. A watchful evaluation is needed to identify underlying conditions potentially associated with AvWD [1-5,7,8].

The diagnosis is confirmed through laboratory work-up, demonstrating quantitative or functional vWF anomalies, thus permitting to unveil the pathogenic mechanism [1-5,7,8 19,21-23].
- Assays that evaluate vWF function:

- $\quad$ ristocetin cofactor activity (vWF:RCo) and collagen binding activity (vWF:CBA) are decreased in some cases, ussualy in lymphoproliferative disorders; in cardiovascular diseases they are normal or subnormal;

- $\quad$ ristocetin induced platelet aggregation (RIPA) is frequently decreased.

- Assays that evaluate vWF biosynthesis:

- $\quad \mathrm{vW}$ antigen (vWF:Ag) is decreased in hypothyroidism and sometimes in 
lymphoproliferative disorders; in myeloprolipherative disorders it is normal/ subnormal;

- $\quad$ vW propeptide (vWFpp, vWF:AgII) is decreased in hypothyroidism but is ussualy increased in other causes of AvWD; an increased vWFpp/vWF:Ag ratio shows normal synthesis and increased clearance of vWF.

- Function/antigen ratio ( $\mathrm{VvWF}_{\mathrm{R}} \mathrm{RCo} / \mathrm{Ag}$ or $\mathrm{vWF}: \mathrm{CBA} / \mathrm{Ag}$ ) is reduced indicating structural or functional disorders.

- $\quad$ VWF multimer analysis is important in AvWD diagnosis especially in cardiovascular disease, uremia or other conditions associated with proteolysis.

The assay is highly sensitive and shows specific patterns of vWF multimer alterations for different associated disorders (lymphoproliferative, meyloproliferative, cardiovascular). Unfortunately, multimer analysis is not largely available and not standardized.

- Flow cytometric analysis demonstrates adsobtion of vWF onto cell surface by detecting ectopic expression of GPIb, $\alpha \operatorname{IIb} \beta 3$ or other platelet receptors.

- $\quad$ Mixing tests or enzyme-linked immunosorbent assay (ELISA) are used to reveal anti-VWF autoantibodies.

AvWD treatment has two major objectives: control of bleeding and therapy or correction (if possible) of the underlying condition. Hemorrhage therapy may employ desmopressin (DDAVP), concentrates containing vWF, recombinant factor VII, antifibrinolytics, intravenous immunoglobulins (IVIG) (in AvWD associated to IgG monoclonal gammopathies), plasmapheresis (in AvWD associated to IgM monoclonal gammopathies). Treatment of the underlying disease may control AvWD's manifestations and is specific for each condition: chemothera-

Table 2. Major pathogenic mechanisms of acquired von Willebrand disease [1,2,4,7,8,12-15,17-22]

\begin{tabular}{|c|c|c|}
\hline Level of vWF synthesis & Mechanism & Underlying disorders \\
\hline Decreased & Decreased vWF biosynthesis & $\begin{array}{l}\text { Hypothyroidism } \\
\text { Drugs (valproic acid) }\end{array}$ \\
\hline \multirow{4}{*}{$\begin{array}{l}\text { Normal synthesis asso- } \\
\text { ciated with accelerated } \\
\text { clearance of vWF from } \\
\text { plasma }\end{array}$} & $\begin{array}{l}\text { Autoantibodies (inhibitors or } \\
\text { nonspecific), immune complex } \\
\text { formation and clearance }\end{array}$ & $\begin{array}{l}\text { Lymphoproliferative disorders (MGUS, MM, NHL) } \\
\text { Autoimmune disease (SLE, connective tissue diseases) } \\
\text { Solid tumors (gastric adenocarcinoma) }\end{array}$ \\
\hline & $\begin{array}{l}\text { Adsorbtion on cell surfaces or } \\
\text { molecules }\end{array}$ & $\begin{array}{l}\text { Lymphoproliferative disorders (MM,WM, NHL, HCL) } \\
\text { Myeloproliferative disorders (ET, PV, CML) } \\
\text { Solid tumors (adrenal cell carcinoma) } \\
\text { Cardiovascular diseases (aortic stenosis) } \\
\text { Drugs (HES) }\end{array}$ \\
\hline & Increased proteolysis & $\begin{array}{l}\text { Myeloproliferative disorders (ET, PV, CML) } \\
\text { Cardiovascular diseases (cardiac valve diseases) } \\
\text { Uremia } \\
\text { Drugs (ciprofloxacin) }\end{array}$ \\
\hline & $\begin{array}{l}\text { Mechanical destruction of mul- } \\
\text { timers }\end{array}$ & Cardiovascular diseases (aortic stenosis) \\
\hline
\end{tabular}

vWF - von Willebrand factor; MGUS - monoclonal gammopathy of undetermined significance; MM - multiple myeloma; NHL - non-Hodgkin's lymphoma; WM - Waldenstrom's macroglobulinemia; HCL - hairy cell leukemia; ET - essential thrombocythemia; PV - polycytemia vera; CML - chronic myeloid leukemia; HES - hidroxyethyl starch 
py (lymphoproliferative disorders), cytoreduction (myeloproliferative syndromes), corrective surgery (cardiac valves anomalies), surgery and/ or radio-/chemotherapy (solid tumors), immunosuppression (autoimmune disorders), thyroxin (hypothyroidism) [1-5,7,8,16,21,22,24,25].

\section{Case reports}

As a practical illustration of the theoretical aspects discussed above we present 3 clinical cases of AvWD diagnosed at the Colţea Hospital Department of Hematology during the last 10 years. All patients consented to the use of their medical data. The publication received approval of the institution's Ethics Committee. In all cases unexpected bleeding signs associated to various underlying conditions led to specialized tests for the evaluation of hemostasis. Coagulation parameters, evaluated with a STACompact (Stago) coagulation analyzer, from 3.2\% trisodium citrate sample tubes included: coagulation factor VIII (STA-ImmunoDef VIII, Stago), prothrombin time (PT) (STA-Neoplastine R, Stago), activated partial thromboplastin time (APTT) (STA-Cephascreen, Stago), Thrombin Time (TT) (STA-Thrombin) and fibrinogen (Fbg) (STA-Liquid Fib, Stago). The quantitative determination of VWF:Ag in plasma was performed by immunoturbidimetric method, using the STA-Liatest VWF:Ag kit (Stago) on a STACompact analyzer. Platelet aggregation was assessed in whole blood by multiple electrode aggregometry (MEA) or impedance aggregometry (Multiplate analyzer, Roche) and expressed by the area under the aggregation curve (AUC) - arbitrary units (AU) plotted against the time (AU*min). Platelets were stimulated by the following agonists: adenosine diphosphate (ADP) (ADPtest, Roche) with a final concentration of $6.5 \mu \mathrm{M}$, collagen (COLtest, Roche) with a final concentration of $3.2 \mu \mathrm{g} / \mathrm{mL}$, thrombin receptor activating peptide-6 (TRAPtest, Roche) with a final concentration of $32 \mu \mathrm{M}$, arachidonic acid
(ASPItest) with a final concentration of $0.5 \mathrm{mM}$ and ristocetin (RISTOtest) with a final concentration of $0.2 \mathrm{mg} / \mathrm{mL}$. Multimer analysis of $\mathrm{vWF}$ was not available.

\section{Clinical case 1 - Hypothyroidism associated AvWD}

A 46 years old woman was referred to our Department for moderate anemia. Anamnesis revealed progressive fatigue and mild weight gain associated with the occurrence of spontaneous ecchymoses, moderate but repetitive epistaxis and gum bleeding. The cell blood count showed moderate anemia (hemoglobin $(\mathrm{Hb}) 8 \mathrm{~g} / \mathrm{dl}$ ) with normocytosis and macrocytosis (MCV 100fl), normal leukocyte $\left(4.8 \times 10^{9} / \mathrm{L}\right)$ and platelet $(330$ x $\left.10^{9} / \mathrm{L}\right)$ counts. Coagulation evaluation was normal, but bleeding time was prolonged (6 $\mathrm{min}), \mathrm{vWF}: \mathrm{Ag}$ was decreased (40\%) and ristocetin induced platelet aggregation was altered (810 AU*min; normal range 980-1180 $\mathrm{AU}^{*}$ min). Further evaluation showed increased thyroid stimulating hormone (TSH) $(6.2 \mu \mathrm{U} / \mathrm{mL}$; normal range 0.6-4.6 $\mu \mathrm{U} / \mathrm{mL}$ ) plasma levels, low thyroxine (T4) (3.9 $\mu \mathrm{g} / \mathrm{dL}$; normal range 5.13-14.1 $\mu \mathrm{g} / \mathrm{dL}$ ) levels and the absence of anti-thyroid peroxidase antibodies (ATPO), thus demonstrating hypothyroidism as the AvWD cause. The patient received treatment with thyroxin leading to a resolution of all hemorrhagic manifestations.

\section{Clinical case 2 - Aortic stenosis associated AvWD}

A 48 years old man diagnosed in 2013 with moderate aortic stenosis was investigated earlier this year for the spontaneous painful tumefaction of both knees. All tests for inflammatory and immune diseases were negative so an articular punction was performed, showing hemarthrosis. At the same time, cardiologic reevaluation showed progression of the aortic stenosis. Clinical examination on admission in our service showed mild knee tumefaction and pain 
without other bleedings. Anamnesis revealed no history of personal or familial hemorrhagic events. Blood count, coagulation tests, bleeding time, coagulation factor levels and $\mathrm{vWF}: \mathrm{Ag}$ were within normal range. Platelet aggregation studies showed normal response to stimulation with ADP, arachidonic acid and collagen, but decreased platelet aggregation after induction with ristocetin (610 AU* min; normal range 980-1180 $\mathrm{AU}^{*} \min$ ) (Figure 1); VvWF:RCo was decreased
(38\%), as was vWF:RCo/Ag (0.4). The patient was referred to a cardiac surgery service to be evaluated for corrective surgery.

\section{Clinical case 3 - Chronic myeloid leukemia associated AvWD}

A 55 years old woman was admitted to our Department for leukocytosis. Her medical history revealed arterial hypertension, progressive fatigue over the past 5 months and recent occur-

\section{A. Case 2}

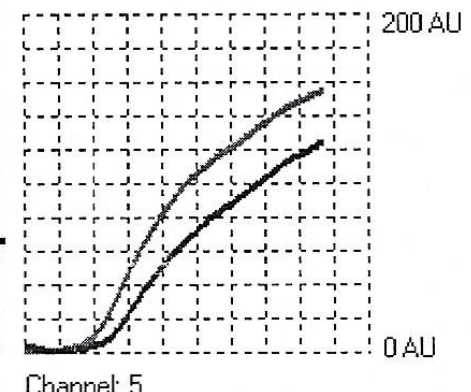

\section{B. Case 3 - at diagnosis}

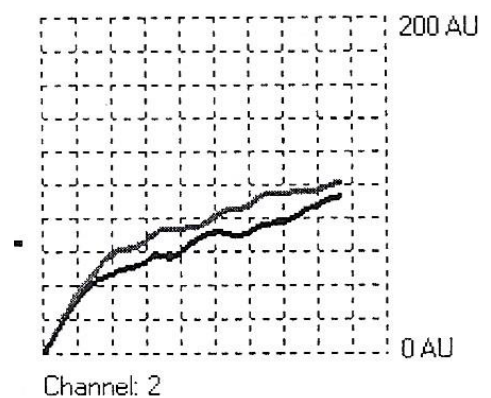

Patient id:

Test name : RISTO high (citrated blood), V1

Start of Test : 05. Aug. 2015, 09:48:49 (Measurement duration 6:00 min.)

Area under the curve : $610 . \Delta U^{x}$ min. [0 - 0]

Aggregation : RUD: $139.1 \mathrm{AU}$

Velocity : RUO: $21.0 \mathrm{AU} / \mathrm{min}$.

Difference fiom mean : $17.281 \%$

Correlation coefficient : 0.992

\section{Case 3 - after treatment with desmopressin, FVIII/VWF complex, cytoreduction}

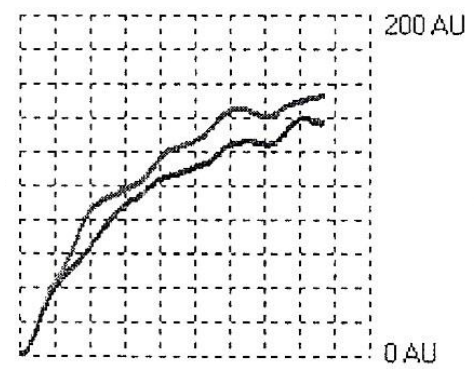

Channel: 1

\author{
Patient id: \\ Test name : RISTO high [citrated blood], V1 \\ Start of Test : 11. Nov. 2015, 12:35:20 (Measurement duration 6:00 min.) \\ Area under the curve : $918 \mathrm{AU}^{*} \mathrm{~min} .(0-0)$ \\ Aggregation : RUD: $145.9 \mathrm{AU}$ \\ Velocity : RUO: $29.5 \mathrm{AU} / \mathrm{min}$. \\ Difference from mean : $6.536 \%$ \\ Correlation coefficient : 0.995
}

FVIII - coagulation factor VIII, vWF - von Willebrand factor

Figure 1. Results of ristocetin induced platelet aggregation assays in cases 2 and 3. 
rence of spontaneous ecchymoses and subcutaneous hematomas. Clinical examination showed several ecchymoses on the upper and lower limbs and splenomegaly ( $8 \mathrm{~cm}$ below costal margin). Blood count showed moderate anemia $(\mathrm{Hb}=9.8$ $\mathrm{g} / \mathrm{dl})$, marked leukocytosis $\left(428 \times 10^{9} / \mathrm{L}\right)$, normal platelet level $\left(256 \times 10^{9} / \mathrm{L}\right)$, a differential count with leftward shift and basophilia (12\% blasts, $12 \%$ promyelocytes, $14 \%$ myelocytes, $14 \%$ metamyelocytes, $40 \%$ neutrophils, $3 \%$ basophils, 3\% eosinophils, 1\% lymphocytes, 1\% monocytes). Routine coagulation (APTT, PT, $\mathrm{INR}, \mathrm{Fbg}$ ) tests were normal. Molecular biology testing showed the presence of the BCR/ABL mutation confirming the diagnosis of chronic myeloid leukemia, accelerated phase. She received cytoreductive treatment with hydroxiureea. During the third day after admission the patient complained of a lumbar pain that referred towards the left thigh and was associated with an antalgic position of the left lower limb (flexion and internal rotation). The pain was associated with extensive subcutaneous hemorrhagic suffusions of the abdominal wall and an abrupt drop in $\mathrm{Hb}$ level to $6.2 \mathrm{~g} / \mathrm{dl}$. Ultrasonographic and MRI examinations showed a massive hematoma $(13 / 10 / 6,5 \mathrm{~cm})$ in the left ileo-psoas muscle with extension into the depth of the abdominal wall. The patient received substitution with packed red cells, fresh frozen plasma and cryoprecipitate. Reevaluation of coagulation showed repeatedly normal routine tests along with normal coagulation factors plasma levels. Further evaluation showed normal vWF:Ag - 119\% but with severe a decrease in platelet aggregation after stimulation with ristocetin (594 $\left.\mathrm{AU}^{*} \min \right)$ (Figure 1), vWF:RCo (19\%) and vWF:RCo/Ag (0.16). The treatment was completed with desmopressin and FVIII/vWF concentrate. After 2 days of substitution therapy and cytoreduction combined treatment we noted the amelioration of pain and abdominal wall hematoma, in parallel with a $\mathrm{Hb}$ increase and a white blood cell count de- crease $\left(65 \times 10^{9} / \mathrm{L}\right)$. Reevaluation of hemostasis showed the increase of VWF:Ag to $150 \%$ and an improvement in platelet aggregation after stimulation with ristocetin (918 $\left.\mathrm{AU}^{*} \min \right)$ (Figure 1). Imagistic reevaluation showed substantial reduction of the ileo-psoas hematoma $(7 / 4 / 2 \mathrm{~cm})$. The patient was released from our Department with the recommendation to start tyrosine kinase inhibitor therapy and a weekly follow-up.

Figure 1 shows the graphical representation of results of ristocetin induced platelet aggregation assays performed in cases 2 and 3 .

\section{Discussions}

Case 1. In patients with hypothyroidism, AvWD is considered the main etiology of hemorrhage. Manfredi et al. published a systematic review including epidemiologic studies and 47 case reports in which diagnostic tests were available as follows: vWF:Ag in 23 cases, vWF activity in 24 cases and FVIII activity in 16 cases. [24]. A recent study performed by Stuijver et al. on 90 patients with overt hypothyroidism at diagnosis showed a mild vWF:Ag and/or vWF:RCo decrease (range $30-50 \%$ ) in $33 \%$ of cases, corelated with the severity of bleeding and levels of free T4. Patients responded to thyroid replacement treatment [25].

In our case, bleeding was associated with clinical and laboratory signs of hypothyroidism. The diagnosis of AvWD was established by demonstrating the decline in vWF synthesis (low vWF:Ag) and moderate impairement of vWF function (ristocetin induced platelet agregation) but in the absence of the vWF:RCo assay. The patient had a very good response to thyroxine therapy.

Case 2. The subject of cardiovascular disease-associated AvWD is actual. In the report published in 2000 by the International Society of Thrombosis and Hemostasis (ISTH) 21\% of 300 AvWD cases were associated with cardio- 
vascular disorders. In recent studies the frequency of cardiovascular associated AvWD rises to $40-46 \%$ reflecting higher awareness among physicians. In selected patient groups AvWD has been diagnosed in $79 \%$ of patients with aortic stenosis $[5,6,10]$. In the vast majority of cases there is a loss of large vWF multimers and decreased vWF:CB/vWF:Ag besides vWF:RCo/ vWF:Ag ratios. The incidence and severity of hemorrhage was correlated with a higher transvalvular gradient and the degree of multimers loss. Cardiac corrective surgery is followed by a rapid improvement of vWF abnormalities [21]. In the reported case the diagnosis was confirmed by decreased ristocetin induced platelet aggregation, vWF:RCo and vWF:RCo/vWF:Ag ratio in the presence of normal vWF:Ag levels. Articular bleeding occurred 2 years after the diagnosis, in association with an aggravation of the aortic stenosis, thus illustrating the correlation between a higher valvular gradient and the severity of coagulation anomalies leading to a clinically significant hemorrhage.

Case 3. CML associated AvWD is less frequently reported. In most myeloproliferations occurrence of AvWD is related to high platelet counts. Clinical manifestations usually consist in moderate muco-cutaneous hemorrhage. $[1,2,4,7,8,12,13,18-20]$. Our patient had normal platelet count but associated marked leukocytosis. The hemorrhagic syndrome was severe with massive intramuscular hematoma and secondary anemia. The major bleeding was controlled only after substitution therapy and cytoreduction.

\section{Conclusions}

Acquired von Willebrand disease is a rare but potentially severe, even fatal, hemorrhagic disorder associated to a multitude of underlying disorders. Because of its reduced incidence and the necessity of an experienced laboratory,
AvWD is probably highly underdiagnosed or misdiagnosed. The first step towards a correct diagnosis is the awareness of physicians in front of patients with AvWD-associated diseases presenting unusual bleeding. Treatment of the underlying disease (when possible) allows in most cases the control of hemorrhage. These are the reasons why all AvWD cases should be reported in order to gain experience in this rare disease, permitting the improvement of diagnostic and therapeutic skills.

\section{Disclosures}

There is no conflict of interest between authors in this study. The manuscript has been read and approved by all the authors, and each author believes the manuscript represents honest work.

\section{References}

1. Shetty S, Kasatkar P, Ghosh K. Pathophysiology of acquired von Willebrand disease: a concise review. Eur J Haematol 2011; 87(2):99-106. DOI: 10.1111/j.16000609.2011.01636.x

2. Franchini M, Lippi G. Acquired von Willebrand syndrome: an update. Am J Hematol. 2007;82(5):368-75. DOI: 10.1002/ajh.20830

3. Mohri H. Acquired von Willebrand syndrome: Its pathophysiology, laboratory features and management. J Thromb Thrombolysis. 2003;15(3):141-9. DOI: 10.1023/B:THRO.0000011369.70824.e6

4. Mohri H. Acquired von Willebrand syndrome: features and management. Am J Hematol. 2006;81(8):616-23. DOI: 10.1002/ajh.20455

5. Tiede A, Rand JH, Budde U, Ganser A, Federici AB. How I treat the acquired von Willebrand syndrome. Blood. 2011;117(25):6777-85. DOI: 10.1182/ blood-2010-11-297580

6. Federici AB, Rand JH, Bucciarelli P, Budde U, Van Genderen PJJ, Mohri H, et al. Acquired von Willebrand syndrome: data from an International registry. Thromb Haemost. 2000;84(2):345-9.

7. Tiede A. Diagnosis and treatment of acquired von Willebrand syndrome. Thrombosis Research. 2012;130(Suppl.2):S2-S6. DOI: 10.1016/S0049-3848(13)70003-3

8. Federici AB. Budde U, Castaman G, Rand HR, Tiede A. Current diagnostic and therapeutic approaches to patients with acquired von Willebrand syndrome: a 2013 update. Semin Thromb Hemost. 2013;39(2):191-201. DOI: $10.1055 / \mathrm{s}-0033-1334867$ 
9. Boissier E, Darnige L, Dougados J, Arlet JB, Dupeux S, Georgin-Lavialle S, et al. Acquired von Willebrand syndrome: A case series of nine patients and literature review. Rev Med Interne. 2014;35(3):154-9. DOI: 10.1016/j.revmed.2013.02.039

10. Budde U, Bergmann F, Michiels JJ. Acquired von Willebrand syndrome: experience from 2 years in a single laboratory compared with data from the literature and an international registry. Semin Thromb Hemost. 2002;28(2):227-38. DOI: $10.1055 / \mathrm{s}-2002-27824$

11. Federici AB, Budde U, Rand JH. Acquired von Willebrand syndrome 2004: International registry. Hamostaseologie. 2004;24(1):50-5.

12. Federici AB. Acquired von Willebrand syndrome: an underdiagnosed and misdiagnosed bleeding complication in patients with lymphoproliferative and myeloproliferative disorders. Semin Hematol 2006;43(1 Suppl 1):S48-58. DOI: 10.1053/j.seminhematol.2005.11.003

13. Vincentelli A, Susen S, Le Tourneau T, Six I, Fabre O, Juthier $\mathrm{F}$, et al. Acquired von Willebrand syndrome in aortic stenosis. N Engl J Med. 2003;349(4):343-9. DOI: 10.1056/NEJMoa022831

14. Fukumoto Y. Impact of acquired von Willebrand syndrome in severe aortic stenosis. J Atheroscler Thromb. 2015;22(11):1113-4. DOI: 10.5551/jat.ED024

15. Tamura T, Horiuchi H, Imai M, Tada T, Shiomi H, Kuroda M, et al. Unexpectedly High Prevalence of Acquired von Willebrand Syndrome in Patients with Severe Aortic Stenosis as Evaluated with a Novel Large Multimer Index. J Atheroscler Thromb. 2015 Nov 2;22(11):1115-23. DOI: 10.5551/jat.30809

16. Zoghi B, Shaughnessy P, Lyons RM, Helmer R, Bachier C, LeMaistre CF. Treatment of Acquired von Willebrand Syndrome and Prevention of Bleeding Postautologous Stem Cell Transplant during Severe Pancytopenia with IVIG. Case Rep Hematol. 2015;2015:809313. DOI: $10.1155 / 2015 / 809313$

17. Franchini M, Castaman G, Coppola A, Santoro C, Zanon E, Di Minno G, et al. Acquired inhibitors of clotting factors: AICE recommendations for diagnosis and management. Blood Transfus. 2015;13(3):498-513.
18. Lancelloti S, Dragani A, Ranalli P, Petrucci G, Basso $\mathrm{M}$, Tartaglione $\mathrm{R}$, et al. Qualitative and quantitative modifications of von Willebrand factor in patients with essential thrombocythemia and controlled platelet count. J Thromb Haemost. 2015;13(7):1226-37. DOI: $10.1111 /$ jth. 12967

19. Scrobohaci ML, Daniel MT, Levy Y, Marolleau JP, Brouet JC. Expression of GpIb on plasma cells in a patient with monoclonal $\mathrm{IgG}$ and acquired von Willebrand disease. Br J Haematol. 1993;84(3):471-5. DOI: 10.1111/j.1365-2141.1993.tb03103.x

20. Pareti FI, Lattuada A, Bressi C, Zanobini M, Sala A, Steffan A, Ruggeri ZM. Proteolysis of von Willebrand factor and shear stress-induced platelet aggregation in patients with aortic valve stenosis. Circulation. 2000;102(11):1290-5. DOI: 10.1161/01. CIR.102.11.1290

21. Kruse-Jarres R. Acquired bleeding disorders in the elderly. Hematology Am Soc Hematol Educ Program. 2015. 2015(1):231-6. DOI: 10.1182/asheducation-2015.1.231

22. Pipe N, Goldenberg N. Acquired Disorders of Hemostasis. In Orkin SH, Fisher DE, Ginsburg D, Look TA, Lux SE, Nathan DG Eds. Nathan and Oski's Hematology and Oncology of Infancy and Childhood 8th Ed. Elsevier Saunders, Philadelphia. 2015:1103-24.

23. Tiede A, Priesack J, Werwitzke S, Bohlmann K, Oortwijn B, Lenting P, et al. Diagnostic workup of patients with acquired von Willebrand syndrome: a retrospective single centre cohort study. J Thromb Haemost. 2008;6(4):569-76. DOI: 10.1111/j.15387836.2008.02909.x

24. Manfredi E, van Zaane B, Gerdes V.E.A, Brandjes D.P.M, Squizzato A. Hypothyroidism and acquired von Willebrand's syndrome: a systematic review. Haemophilia. 2008;14(3):423-33. DOI: 10.1111/j.13652516.2007.01642.x

25. Stuijver DJ, Piantanida E, van Zaane B, Galli L, Romualdi E, Tanda ML, et al. Acquired von Willebrand syndrome in patients with overt hypothyroidism: a prospective cohort study. Haemophilia. 2014;20(3):32632. DOI: $10.1111 /$ hae. 12275 
